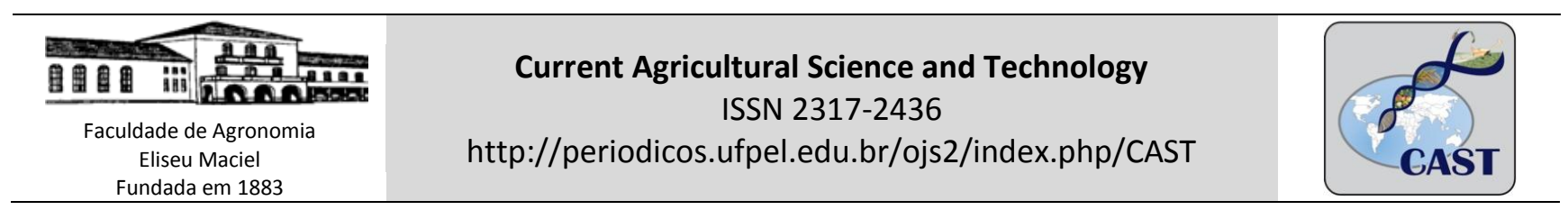

\title{
Physicochemical and sensory properties of popcorn grain stored at different temperatures
}

\author{
Ricardo Tadeu Paraginski ${ }^{1}$, Valmor Ziegler ${ }^{2}$, Márcio Peter ${ }^{2}$, Bruno Artur Rockenbach ${ }^{2}$, Nathan Levien \\ Vanier $^{2 *}$, Moacir Cardoso Elias ${ }^{2}$ \\ ${ }^{1}$ Federal Institute Farroupilha, Campus Alegrete, RS 377, Km 27, Passo Novo, CEP: 97541-970, Alegrete, Brazil. \\ ${ }^{2}$ Department of Agroindustrial Science and Technology, Federal University of Pelotas, 96160-000 Pelotas, Brazil. \\ *Corresponding author: N. L. Vanier \\ E-mail: nathanvanier@hotmail.com
}

\section{ABSTRACT}

Popcorn is produced and consumed worldwide, requiring storage to address the demands of consumers throughout the year because production is generally seasonal. Several factors can affect the quality of stored grains, including storage temperature. This study aims to evaluate the effects of different storage temperatures (5, 15,25 and $35{ }^{\circ} \mathrm{C}$ ) on the physicochemical, technological, pasting and sensory properties of popcorn grains stored for 6 months. The storage at $35^{\circ} \mathrm{C}$ for 6 months promoted an increase in the expansion time and a decrease in the weight of the expanded popcorn as well as a decrease in electrical conductivity, $\mathrm{pH}$ and protein solubility of popcorn. Moreover, the greater residue content after expansion was found for grains stored at 35 ${ }^{\circ} \mathrm{C}$. These characteristics were reflected in the purchase intent test and in the sensory evaluation. Expanded popcorn prepared with grains stored at $15{ }^{\circ} \mathrm{C}$ exhibited larger flower and higher purchase intent characteristics than expanded popcorn prepared from other treatments, when evaluated by the sensory panel. Considering these benefits, storage at lower temperatures of approximately $15{ }^{\circ} \mathrm{C}$ is preferable to preserve the physical, sensory and technological properties of popcorn.
Keywords: popcorn; storage temperature; grain quality; sensory evaluation; purchase intent.

\section{INTRODUCTION}

Popcorn grains (Zea mays L. everta) are produced mainly in the Americas, being exclusively used for human consumption. In Brazil, the annual production of popcorn is 80,000 tons (Miranda, 2011). In recent years, due to the nutritional and sensory properties, consumers' demand for high-quality popcorn has grown. As is the case with other crops, popcorn must be stored in the off-season to supply the continuous consumer demand throughout the year. Several factors must be controlled for the prevention of the qualitative and quantitative losses of popcorn grains during the storage period, such as grain moisture content and the temperature of the storage environment.

According to Reed et al. (2007) and Park et al. (2012), the factors that affect the quality of grain during storage are moisture content and temperature of the grains and air; presence of broken grains, foreign matter and impurities; attack of insects, mites and microorganisms; and technical handling and storage time. Among these factors, temperature should be highlighted. 
Temperature control of stored grains can be achieved by aeration with ambient air, which is not always possible. In tropical regions, the temperatures are high, making it nearly impossible to reduce the temperature of the stored grain mass by aerating them with the ambient air. In these cases, artificial cooling techniques may be used.

Some studies have been conducted to evaluate the effects of storage temperature on the physicochemical and technological properties of maize (Paraginski et al., 2014a; Paraginski et al., 2014b), rice (Silva et al., 2014; Park et al., 2012; Zhou et al., 2010; Zhou et al., 2003), fava (NasarAbbas et al., 2008), beans (Vanier et al., 2014; Yousif et al., 2003), lentil (Rani et al., 2013) and soybean (Lee and Cho, 2012). However, to our knowledge, there is a lack of information regarding the effects of storage temperature on the quality of popcorn grains. Paraginski et al. (2014b), evaluated the physicochemical properties of maize stored at different temperatures $\left(5,15,25\right.$ and $\left.35^{\circ} \mathrm{C}\right)$ for 12 months and found that temperatures above $25^{\circ} \mathrm{C}$ reduces the $\mathrm{pH}$, protein solubility and color intensity of the grains and increases fat acidity and starchprotein interactions.

Considering the importance of popcorn storage for supporting demand during the offseason, the lack of information on the effects of storage temperature on the quality of popcorn, and the growing consumption of these grains, this study aimed to evaluate the effects of different storage temperatures $\left(5,15,25\right.$ and $\left.35^{\circ} \mathrm{C}\right)$ on the physical, technological, pasting and sensory properties of popcorn grain stored for 6 months.

\section{MATERIAL AND METHODS}

\section{Material and sample preparation}

Popcorn grains of the yellow class (Zea mays L. everta) were used. The grains were produced in the 2013 growing season in Santo Augusto, State of Rio Grande do Sul, Brazil (S $27^{\circ} 53^{\prime \prime} 18^{\prime \prime}$, W $53^{\circ} 47^{\prime \prime} 20^{\prime \prime} ; 489$ meters of altitude). The grains were harvested at $18 \%$ moisture content and then submitted to a drying process at room temperature $\left(25{ }^{\circ} \mathrm{C}\right)$ until $13 \%$ moisture content was achieved. Next, the dried grains were transported to Laboratório de Pós-Colheita, Industrialização e Qualidade de Grãos of DCTAFAEM-UFPel, where the experiments were performed. The grains were stored in polyethylene bags $(0.2-\mathrm{mm}$ thick plastic film with a capacity for storing $900 \mathrm{~g}$ of grains) at temperatures of $5,15,25$, and $35^{\circ} \mathrm{C}$ for 6 months, in triplicate. The grains were maintained covered from light using aluminum foil. The evaluations were performed at baseline and after 6 months of storage before and after expansion (Figure 1). For analysis, the grains were ground in a laboratory mill (Perten 3100, Perten Instruments, Huddinge, Sweden) equipped with a 45-mesh sieve to obtain flour of uniform particle size.

\section{Physical properties of the expansion of popcorn kernels}

The physical properties of expansion time, weight of the expanded popcorn, expansion capacity and expansion residue (content of the non-expanded grains) were determined. Expansion time was determined using a microwave (Model Electrolux Ponto Certo MEP 41, Brazil), with a period of 5 seconds between the expansion of a sample and that of another for determining the final expansion time. The weight of popcorn after expansion was determined using an analytical balance; popcorn was weighed after expansion. The expansion ratio of the popcorn grains was obtained by the ratio between the volume of the obtained popcorn flower and the volume of the non-expanded popcorn grains, in accordance to the method described by Sawasaki et al. (1986), using $30 \mathrm{~g}$ of grains for the expansion procedure. The expansion residue was calculated by the number of non-expanded grains as related to the total number of seeds subjected to the expansion procedure. 


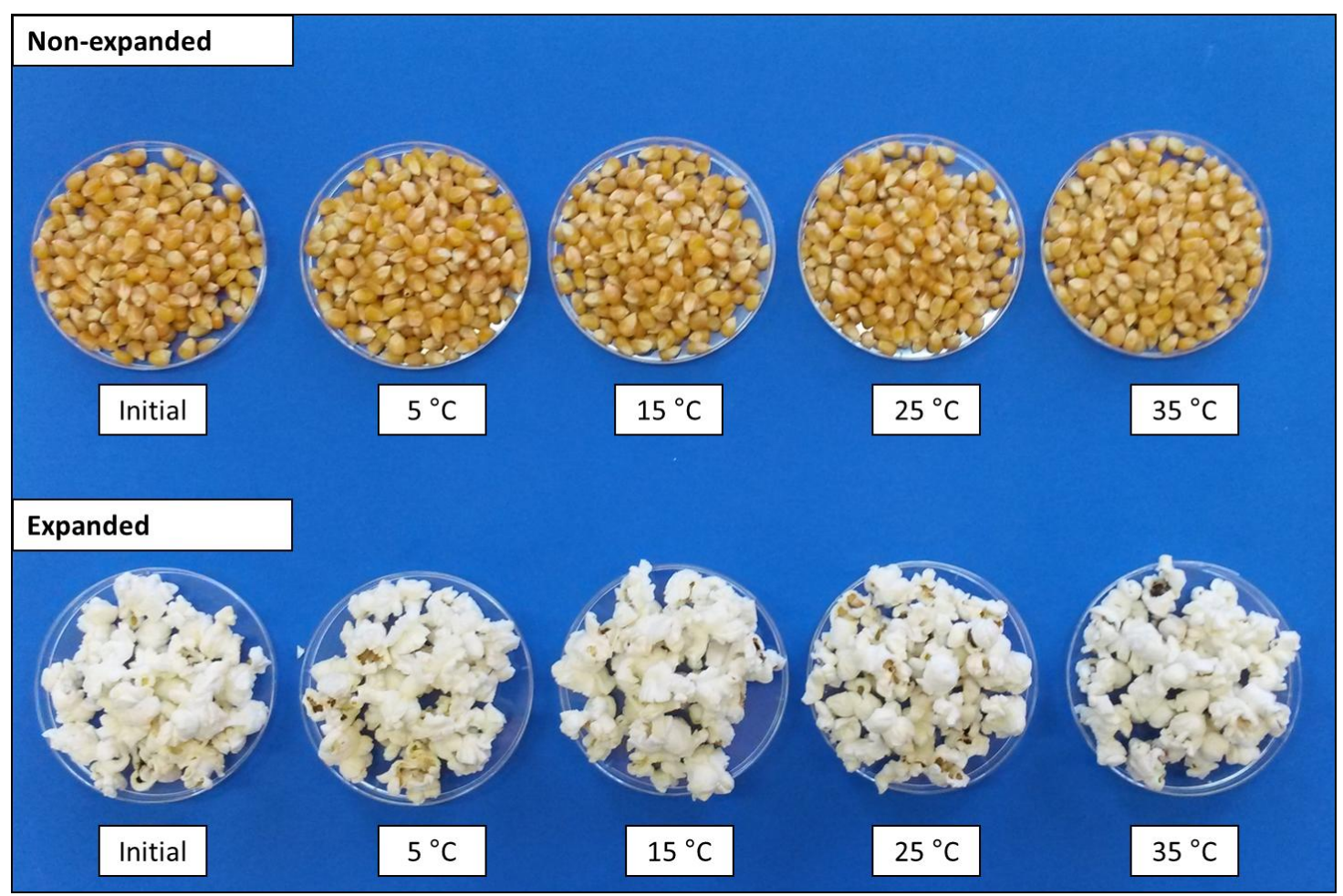

Figure 1. Popcorn grains before and after the expansion process at baseline (initial) and after six months of storage at temperatures of $5,15,25$ and $35^{\circ} \mathrm{C}$.

\section{Physicochemical properties}

The electrical conductivity, $\mathrm{pH}$, fat acidity, and protein solubility of the grains were determined in non-expanded grains. The electrical conductivity of the grains was determined according to the method described by the International Seed Testing Association (ISTA, 2008). $\mathrm{pH}$ was determined on a filtrate of $2 \mathrm{~g}$ of ground sample in $20 \mathrm{~mL}$ of distilled water. The solution was stirred for 1 min using a stir bar, and then the $\mathrm{pH}$ was recorded using a glass electrode $\mathrm{pH}$ meter. Fat acidity was determined using a titrimetric procedure described in the AACC method 02-01A (AACC, 2000). The titratable acidity was expressed as the number of $\mathrm{mg}$ of sodium hydroxide required to neutralize the acids in $100 \mathrm{~g}$ of sample, using phenolphthalein solution as an indicator.

The protein solubility in water was determined according to the method described by Liu et al. (1992), with some modifications. One gram of popcorn flour was dispersed in $50 \mathrm{~mL}$ of distilled water at constant stirring for $1 \mathrm{~h}$. The slurry was centrifuged at $5300 \times g$ for $20 \mathrm{~min}$, and then $2.0 \mathrm{~mL}$ of supernatant was collected for determination of the protein content. Nitrogen content was determined by the Kjeldahl method, and the resulting nitrogen value was converted to protein using the factor 6.25. Protein solubility, expressed in percentage (\%), was calculated by the ratio of soluble protein content to crude protein content.

\section{Pasting properties}

The pasting properties of the maize flour (3.0 g, 14\% moisture basis) were determined via a Rapid Visco Analyzer (RVA-4; Newport Scientific, Warriewood, Australia) using the RVA profile Standard Analysis 1. Viscosity was expressed in rapid visco units (RVU). The sample was held at 50 ${ }^{\circ} \mathrm{C}$ for $1 \mathrm{~min}$, heated to $95{ }^{\circ} \mathrm{C}$ in $3.5 \mathrm{~min}$, and then held at $95{ }^{\circ} \mathrm{C}$ for $2.5 \mathrm{~min}$. The sample was then cooled to $50{ }^{\circ} \mathrm{C}$ in $4 \mathrm{~min}$ and subsequently held at $50{ }^{\circ} \mathrm{C}$ for $2 \mathrm{~min}$. The rotating speed was held at $960 \mathrm{rpm}$ for $10 \mathrm{~s}$ and then maintained at $160 \mathrm{rpm}$ 
during the process. The parameters of pasting temperature, peak viscosity, breakdown, final viscosity and setback were recorded.

\section{Sensory properties}

The sensory evaluation of the expanded popcorn was performed according to the method described by Minim (2006). The survey was conducted with 50 non-trained consumers, including employees, students and visitors from the Federal University of Pelotas, based on the interest and availability of the consumers to participate in the sensory panel. The consumers were from both genders, male and female, and ranged in age from 15 to 45 years old. The assessment panel was set up with samples from the initial storage period and samples from after 6 months of storage. Samples were codified by three numbers each and randomly presented to the panelists. Samples from the initial storage period were maintained at $-20{ }^{\circ} \mathrm{C}$ during the 6 months in order to be used in the assessment panel.

The purchase intent test was performed using a five-point structured scale, namely, definitely would not buy (1), most likely would not buy (2), undecided (3), most likely would buy (4), and definitely would buy (5). Tests were also performed to evaluate the preference as to "color" and "flower size" of the expanded popcorn, and the results were processed by determining the critical values of the total orders of the differences compared to the treatments with each other ( $p \leq 0.05)$, based on the "Friedman test".

\section{Statistical analysis}

Analytical determinations for the samples were performed in triplicate, and the standard deviations are reported. A comparison of the means was ascertained by Tukey's test to a $5 \%$ level of significance using analysis of variance (ANOVA). The results from the sensory test were processed by determining the critical values of the difference of the sum of orders for comparison of the treatments with each other ( $p$ $\leq 0.05)$, based on the Friedman's test.

\section{RESULTS AND DISCUSSION}

\section{Physical properties of the expansion of popcorn kernels}

The physical properties of the expansion of popcorn grains in the initial period of storage and after 6 months of storage at different temperatures are presented in Table 1 . There was an increase $(p \leq 0.05)$ in the expansion time and a reduction $(p \leq 0.05)$ in the weight of the expanded popcorn grains prepared from $35{ }^{\circ} \mathrm{C}$-stored popcorn compared to the other treatments.

The expansion capacity decreased ( $p \leq$ 0.05 ) in the grains stored at 25 and $35{ }^{\circ} \mathrm{C}$ after 6 months compared to the grains at the initial storage period. The expansion residue increased ( $p \leq 0.05$ ) with the increase of the storage temperature. The increase in the expansion residue content may be related to the decrease in the weight of the expanded popcorn and to the decrease in the expansion capacity of the popcorn due to the interactions of the grain's constituents during storage that hinder grain popcorn flower growth during the expansion process. According to Zinsly and Machado (1978), the expansion capacity of commercial popcorn must be greater than $15 \mathrm{~g} \cdot \mathrm{mL}^{-1}$ because below this value, popcorn appears very rigid, with too many grains and without expansion properties.

The expansion capacity results presented in Table 1, regardless of the treatment, are higher than the minimum expansion capacity value indicated by Zinsly and Machado (1978). According to Luz et al. (2005) and Song and Eckhoff (1994), popcorn possesses the greatest expansion capacity at $13 \%$ moisture content. This result is also influenced by the size and the shape of the grains. The ability of popcorn to expand is due to the resistance of its pericarp and vitreous endosperm, which is associated with the presence of fat and moisture within the grain. When 
heated, the starch of popcorn expands, increasing the pressure within the grain until the moment when explosion occurs, which generally occurs when the temperature reaches $180{ }^{\circ} \mathrm{C}$ and the pressure reaches $930.8 \mathrm{kPa}$ (Zinsly and Machado, 1978).

Table 1. Expansion time, weight of expanded popcorn, expansion capacity and expansion residue of popcorn grains at the beginning of the storage period (initial) and at the end of 6 months of storage at 5 , 15,25 and $35^{\circ} \mathrm{C}$.

\begin{tabular}{lcccc}
\hline $\begin{array}{l}\text { Storage } \\
\text { conditions }^{*}\end{array}$ & $\begin{array}{c}\text { Expansion time } \\
(\mathbf{s})\end{array}$ & $\begin{array}{c}\text { Weight of the } \\
\text { expanded popcorn (g) }\end{array}$ & $\begin{array}{c}\text { Expansion capacity } \\
\text { (g.mL } \mathbf{m b}^{-1} \text { ) }\end{array}$ & $\begin{array}{c}\text { Expansion residue } \\
(\%)\end{array}$ \\
\hline Initial & $120.00 \pm 5.00^{\mathrm{b}}$ & $15.55 \pm 1.55^{\mathrm{a}}$ & $31.87 \pm 0.23^{\mathrm{a}}$ & $2.72 \pm 0.59^{\mathrm{e}}$ \\
$5^{\circ} \mathrm{C}$ & $129.00 \pm 2.00^{\mathrm{b}}$ & $14.44 \pm 0.50^{\mathrm{a}}$ & $28.93 \pm 1.01^{\mathrm{a}}$ & $4.40 \pm 1.23^{\mathrm{d}}$ \\
$15^{\circ} \mathrm{C}$ & $129.00 \pm 2.00^{\mathrm{b}}$ & $14.72 \pm 0.30^{\mathrm{a}}$ & $26.40 \pm 0.44^{\mathrm{a}}$ & $8.94 \pm 0.61^{\mathrm{c}}$ \\
$25^{\circ} \mathrm{C}$ & $131.00 \pm 3.00^{\mathrm{b}}$ & $14.56 \pm 0.74^{\mathrm{a}}$ & $23.33 \pm 0.64^{\mathrm{b}}$ & $12.50 \pm 0.45^{\mathrm{b}}$ \\
$35^{\circ} \mathrm{C}$ & $145.00 \pm 5.00^{\mathrm{a}}$ & $13.57 \pm 0.64^{\mathrm{b}}$ & $22.53 \pm 0.29^{\mathrm{b}}$ & $18.04 \pm 0.75^{\mathrm{a}}$ \\
\hline
\end{tabular}

The results are the mean of three replications \pm standard deviation. The values followed by different letters in the same column are significantly different $(p \leq 0.05)$.

\section{Physicochemical properties}

The physicochemical properties of the non-expanded popcorn grains are presented in Table 2. An increase $(p \leq 0.05)$ in the electrical conductivity and a reduction ( $p \leq 0.05$ ) in the protein solubility of the grains stored at $35{ }^{\circ} \mathrm{C}$ were observed, compared to the grains from the initial storage period. No difference ( $p \leq 0.05)$ in electrical conductivity and protein solubility was observed in the grains stored at 5, 15 and $25{ }^{\circ} \mathrm{C}$ compared to the grains from the initial storage period. The $\mathrm{pH}$ of the grains decreased ( $p \leq 0.05)$ in those samples stored at 5 and $35{ }^{\circ} \mathrm{C}$ (Table 2) compared to the grains from the initial storage period. The reduction in $\mathrm{pH}$ could be attributed to the leaching of hydrogen ions from the interior of the grain cells due to cell membrane damage. A similar result was observed in a previous study (Paraginski et al., 2014b), where the highest $\mathrm{pH}$ reduction was observed in maize stored at $35{ }^{\circ} \mathrm{C}$ after 12 months, compared to maize stored at 5 , 15 and $25^{\circ} \mathrm{C}$.

Table 2. Electrical conductivity, $\mathrm{pH}$, fat acidity and protein solubility of popcorn grains at the beginning of the storage period (initial) and at the end of 6 months of storage at 5, 15, 25 and $35^{\circ} \mathrm{C}$.

\begin{tabular}{|c|c|c|c|c|}
\hline $\begin{array}{l}\text { Storage } \\
\text { conditions }\end{array}$ & $\begin{array}{c}\text { Electrical conductivity } \\
\left(\mu \mathrm{S} \cdot \mathrm{cm}^{-1} \cdot \mathrm{g}^{-1}\right)\end{array}$ & $\mathrm{pH}$ & $\begin{array}{c}\text { Fat acidity } \\
\left(\mathrm{mg} \text { de } \mathrm{NaOH} .100 \mathrm{~g}^{-1}\right)\end{array}$ & $\begin{array}{c}\text { Protein solubility } \\
(\%)\end{array}$ \\
\hline Initial & $49.50 \pm 3.11^{a}$ & $6.36 \pm 0.07^{a}$ & $4.57 \pm 0.40^{a}$ & $45.89 \pm 0.78^{a}$ \\
\hline $5^{\circ} \mathrm{C}$ & $45.50 \pm 1.71^{a}$ & $6.28 \pm 0.09^{b}$ & $4.98 \pm 0.33^{a}$ & $44.54 \pm 0.56^{a}$ \\
\hline $15^{\circ} \mathrm{C}$ & $45.00 \pm 2.83^{a}$ & $6.32 \pm 0.03^{a}$ & $4.89 \pm 0.37^{a}$ & $45.34 \pm 0.67^{a}$ \\
\hline $25^{\circ} \mathrm{C}$ & $50.50 \pm 2.16^{a}$ & $6.34 \pm 0.10^{a}$ & $4.87 \pm 0.42^{a}$ & $44.21 \pm 0.45^{a}$ \\
\hline $35^{\circ} \mathrm{C}$ & $53.00 \pm 1.15^{b}$ & $6.25 \pm 0.05^{c}$ & $4.91 \pm 0.45^{a}$ & $38.32 \pm 0.87^{b}$ \\
\hline
\end{tabular}

The results are the mean of three replications \pm standard deviation. The values followed by different letters in the same column are significantly different $(p \leq 0.05)$.

According to Sirisoontaralak and Noomhorm (2007), the predominant fatty acids in maize are polyunsaturated, especially linoleic acid, and are susceptible to oxidation, forming aldehyde, carbonyl, ketone and ester radicals at the end of the oxidation process. However, the fat 
acidity of the popcorn grains were found to remain constant $(p \leq 0.05)$ during the 6 months of storage, regardless of storage temperature (Table 2).

\section{Pasting properties}

The curves from the pasting profile analysis of the popcorn grains are presented in Figure 2, while the data from the pasting profile analysis are presented in Table 3. According to the data presented in Table 3, changes were observed in the pasting temperature, peak viscosity, breakdown, final viscosity and setback of the flours obtained from the grains stored for 6 months, especially for the $35^{\circ} \mathrm{C}$ storage condition, compared to the grains at the beginning of the storage period (initial). Final viscosity increased ( $p$ $\leq 0.05$ ) from $584.59 \mathrm{RVU}$ at the beginning of storage to 644.17 and 632.04 RVU when popcorn grains were stored at 25 and $35{ }^{\circ} \mathrm{C}$, respectively. Setback viscosity increased $(p \leq 0.05)$ from 378.42 RVU at the beginning of storage to 420.34 and 414.17 RVU at the end of 6 months storage at 25 to $35{ }^{\circ} \mathrm{C}$, respectively, confirming that significant changes occurred in the pasting properties of popcorn stored for 6 months at the highest temperatures of 25 and $35{ }^{\circ} \mathrm{C}$

The reduction $(p \leq 0.05)$ in the breakdown value from $35.13 \mathrm{RVU}$ at the beginning of the storage period (initial) to 23.13 and $7.59 \mathrm{RVU}$ for grains stored at 25 to $35{ }^{\circ} \mathrm{C}$, respectively, is related to the increase in starch-protein interactions, which promotes the rigidity of starch granules and, thus, makes them less susceptible to breakage during the constant heating and shearing cycle of the RVA analysis. The greater interaction between starch and proteins determined in the popcorn grains stored at the higher temperatures of 25 and $35{ }^{\circ} \mathrm{C}$ was also responsible for their lower expansion capacity (Table 1) and protein solubility (Table 2) compared to the initial treatment and grains stored at 5 and $15^{\circ} \mathrm{C}$.

According to Zhou et al. (2003), the reduction in the breakdown value is the result that best indicates the changes that occurred during grain storage, which are related to a lower susceptibility of starch granules to collapse during the constant heating and shearing cycle of the RVA analysis. The reduction in the breakdown viscosity and the increase in the pasting temperature observed in the present study for grains stored at the highest temperatures, mainly at $35{ }^{\circ} \mathrm{C}$, are in agreement with the results reported by Paraginski et al. (2014b), who evaluated the effects of the same storage conditions on maize pasting properties and attributed these changes to the strengthening of the interactions between starch and proteins.

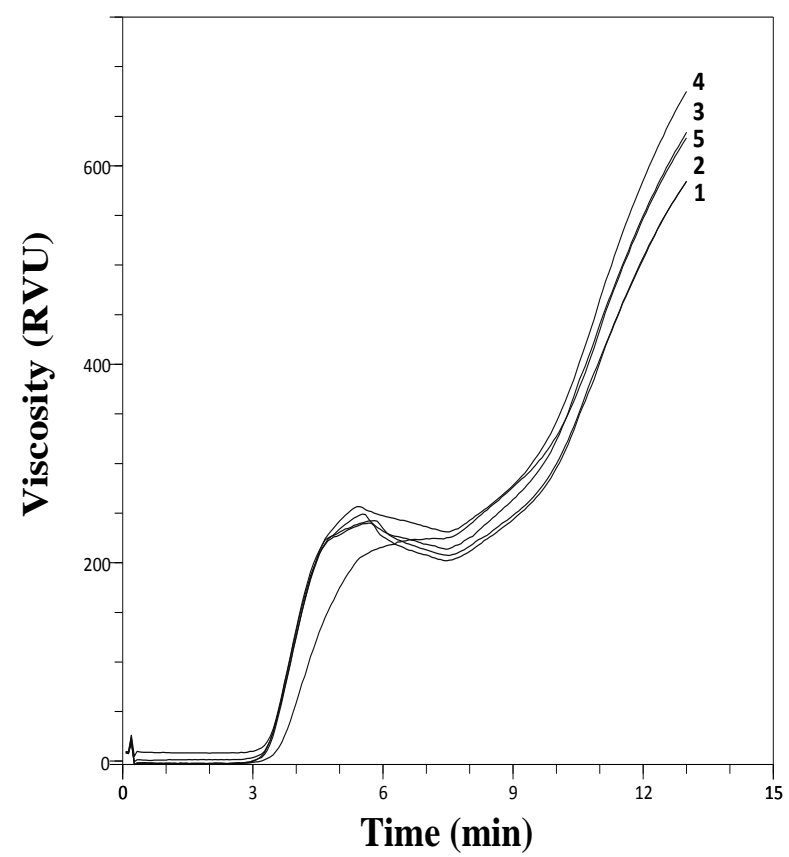

Figure 2. RVA curves of popcorn grains at baseline (1) and after six months of storage at temperatures of $5{ }^{\circ} \mathrm{C}(2) 15^{\circ} \mathrm{C}(3) 25^{\circ} \mathrm{C}(4)$ and 35 ${ }^{\circ} \mathrm{C}(5)$. 
Table 3. Pasting properties of popcorn grains at the beginning of the storage period (initial) and at the end of 6 months of storage at $5,15,25$ and $35^{\circ} \mathrm{C}$.

\begin{tabular}{lccccc}
\hline $\begin{array}{l}\text { Storage } \\
\text { conditions* }\end{array}$ & $\begin{array}{c}\text { Pasting temperature } \\
\left({ }^{\circ} \mathbf{C}\right)\end{array}$ & $\begin{array}{c}\text { Peak Viscosity } \\
\text { (RVU) }\end{array}$ & $\begin{array}{c}\text { Breakdown } \\
\text { (RVU) }\end{array}$ & $\begin{array}{c}\text { Final viscosity } \\
\text { (RVU) }\end{array}$ & $\begin{array}{c}\text { Setback } \\
\text { (RVU) }\end{array}$ \\
\hline Initial & $75.00 \pm 0.00^{\mathrm{b}}$ & $241.29 \pm 1.21^{\mathrm{a}}$ & $35.13 \pm 0.05^{\mathrm{a}}$ & $584.59 \pm 0.42^{\mathrm{c}}$ & $378.42 \pm 1.66^{\mathrm{c}}$ \\
$5^{\circ} \mathrm{C}$ & $76.23 \pm 0.32^{\mathrm{b}}$ & $247.55 \pm 1.63^{\mathrm{a}}$ & $35.13 \pm 2.88^{\mathrm{a}}$ & $594.54 \pm 0.04^{\mathrm{cb}}$ & $382.13 \pm 0.45^{\mathrm{bc}}$ \\
$15^{\circ} \mathrm{C}$ & $75.48 \pm 0.38^{\mathrm{b}}$ & $244.59 \pm 0.58^{\mathrm{a}}$ & $33.17 \pm 2.34^{\mathrm{a}}$ & $623.21 \pm 0.15^{\mathrm{abc}}$ & $411.79 \pm 0.97^{\mathrm{ab}}$ \\
$25^{\circ} \mathrm{C}$ & $75.95 \pm 0.80^{\mathrm{b}}$ & $246.96 \pm 0.54^{\mathrm{a}}$ & $23.13 \pm 2.30^{\mathrm{b}}$ & $644.17 \pm 0.84^{\mathrm{a}}$ & $420.34 \pm 0.59^{\mathrm{a}}$ \\
$35^{\circ} \mathrm{C}$ & $78.20 \pm 0.10^{\mathrm{a}}$ & $225.46 \pm 1.13^{\mathrm{b}}$ & $7.59 \pm 0.34^{\mathrm{c}}$ & $632.04 \pm 0.96^{\mathrm{ab}}$ & $414.17 \pm 1.16^{\mathrm{a}}$ \\
\hline
\end{tabular}

The results are the mean of three replications \pm standard deviation. The values followed by different letters in the same column are significantly different $(p \leq 0.05)$

\section{Sensory properties}

Figure 3 shows the purchase intent of the consumers for the expanded popcorn prepared from popcorn grains stored at different temperatures for 6 months and from grains at the beginning of the storage period. A reduction was observed in the purchase intent of the popcorn prepared with grains stored at $35^{\circ} \mathrm{C}$, since the highest percentage of the responses "Most likely would not buy" and "Definitely would not buy" were observed for the popcorn prepared with grains stored at $35{ }^{\circ} \mathrm{C}$ (Figure $3 e$ ). This result is most likely associated with the more severe changes observed in the pasting and technological properties of popcorn stored at $35{ }^{\circ} \mathrm{C}$, as presented in Tables 1, 2 and 3. The popcorn prepared with grains stored at $5{ }^{\circ} \mathrm{C}$ had the second worst purchase intent, with only $22 \%$ of the respondents stating that "Definitely would buy" the product (Figure 3b). At this temperature, an increase in the viscosity of water occurs, which may cause the breakage of some cell structures. This cell disruption, in turn, leads to the leaching of ions and a pH decrease (as presented in Table 2 ), thus altering the characteristics of the expanded grains.

The sensory evaluation results regarding color and flower size of the expanded popcorn are presented in Table 4. No difference ( $p \leq 0.05)$ was found for the color preference among the samples. However, consumer preference for flower size was higher ( $p \leq 0.05$ ) in expanded popcorn prepared using grain stored at $15{ }^{\circ} \mathrm{C}$ compared to that of the other treatments. This result corroborates with the results of the purchase intent, where, in general, the best purchase intent was observed for grains stored at $15^{\circ} \mathrm{C}$ (Figure 3).

Table 4. Sensory evaluation of popcorn grains at the beginning of the storage period (initial) and at the end of 6 months of storage at 5, 15, 25 and 35 ${ }^{\circ} \mathrm{C}$.

\begin{tabular}{lcc}
\hline \multirow{2}{*}{$\begin{array}{l}\text { Storage } \\
\text { conditions }\end{array}$} & \multicolumn{2}{c}{ Assessment of preference ${ }^{*}$} \\
\cline { 2 - 3 } & Color & Flower size \\
\hline Initial & $147^{\mathrm{a}}$ & $142^{\mathrm{b}}$ \\
$5^{\circ} \mathrm{C}$ & $145^{\mathrm{a}}$ & $129^{\mathrm{b}}$ \\
$15^{\circ} \mathrm{C}$ & $173^{\mathrm{a}}$ & $203^{\mathrm{a}}$ \\
$25^{\circ} \mathrm{C}$ & $150^{\mathrm{a}}$ & $148^{\mathrm{b}}$ \\
$35^{\circ} \mathrm{C}$ & $135^{\mathrm{a}}$ & $128^{\mathrm{b}}$ \\
\hline
\end{tabular}

* The sensory evaluation parameters of "color" and "flower size" of the popcorn grains after expansion were determined by 50 untrained volunteers randomly selected, based on interest and availability to participate; the volunteers were of both sexes and aged between 15 and 45 years. 


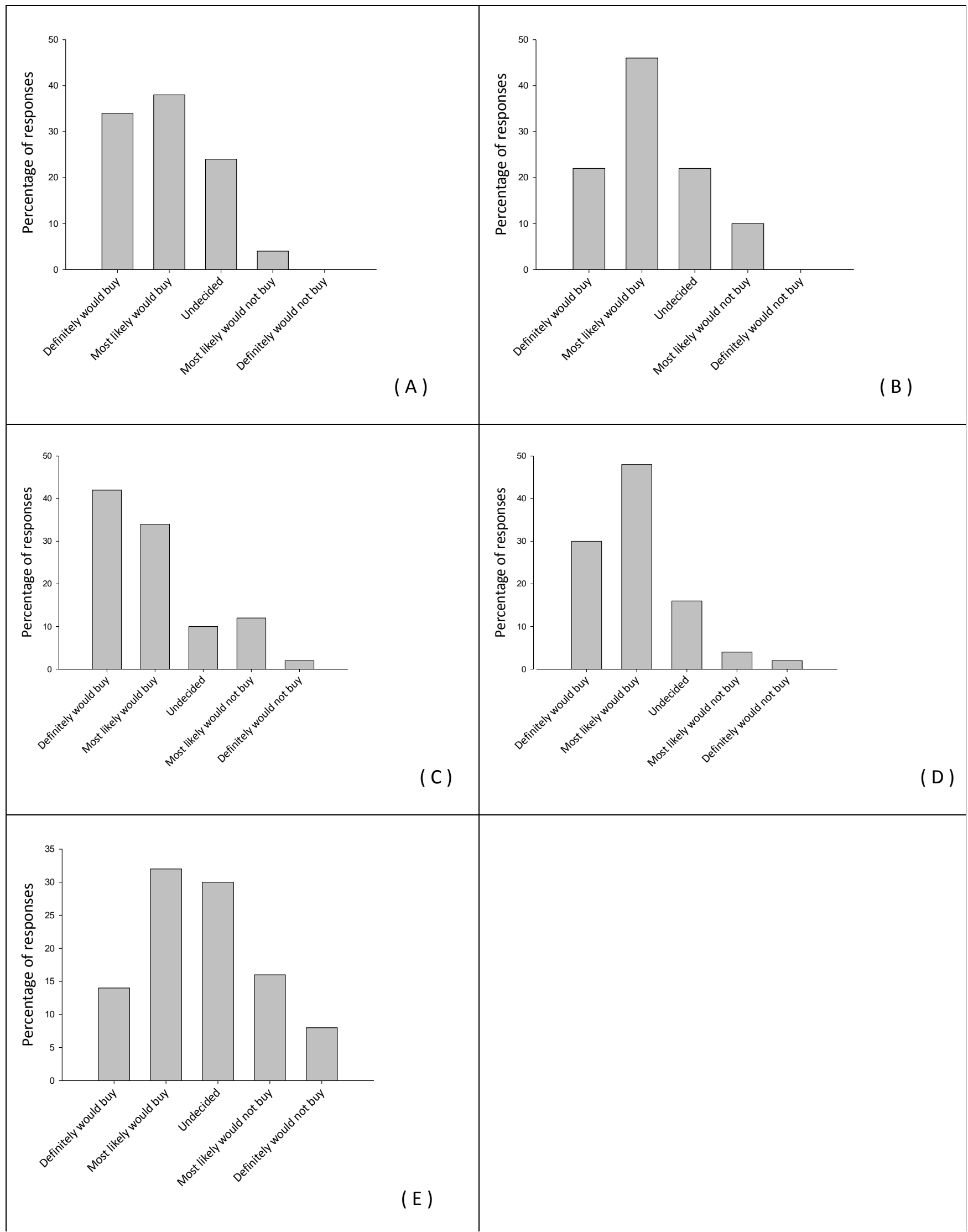

Figure 3. Purchase intent of consumers for expanded popcorn prepared from grains at the beginning of the storage period (a) and after 6 months of storage at $5{ }^{\circ} \mathrm{C}$ (b) $15{ }^{\circ} \mathrm{C}$ (c) $25{ }^{\circ} \mathrm{C}$ (d) and $35{ }^{\circ} \mathrm{C}$ (e). 


\section{CONCLUSIONS}

Storage at $35^{\circ} \mathrm{C}$ for 6 months promoted an increase in the expansion time and reductions in the weight of expanded popcorn and in the electrical conductivity, the $\mathrm{pH}$, and the protein solubility of the popcorn grains used in the present study. Moreover, compared to the initial grains, a greater expansion residue content was presented by the grains stored at the highest temperature of $35{ }^{\circ} \mathrm{C}$. These characteristics were reflected in the purchase intent test and the sensory evaluation results. Expanded popcorn prepared with grains stored at $15^{\circ} \mathrm{C}$ exhibited the highest flower size, in accordance with consumer observations, and better results for purchase intent. For these benefits, storage at lower temperatures of approximately $15^{\circ} \mathrm{C}$ is preferred to preserve the physical, sensory and technological properties of popcorn. In warmer climates, with average temperatures near or above $35{ }^{\circ} \mathrm{C}$, aeration or artificial cooling procedures may be taken to minimize the loss of quality of the stored popcorn grains.

\section{ACKNOWLEDGMENTS}

We thank CAPES (Coordenação de Aperfeiçoamento de Pessoal de Nível Superior), CNPq (Conselho Nacional de Desenvolvimento Científico e Tecnológico), FAPERGS (Fundação de Amparo à Pesquisa do Estado do Rio Grande do Sul), SCT-RS (Secretaria da Ciência e Tecnologia do Estado do Rio Grande do Sul) and Polo de Inovação Tecnológica em Alimentos da Região Sul.

\section{REFERENCES}

AACC (2000) Fat acidity - general method. Method 02-01A. In: Approved Methods of the American Association of Cereal Chemists. American Association of Cereal Chemists, Inc, St. Paul, MN, USA.
AOAC (2006) Association of Official Analytical Chemists. Official methods of Analysis. 18 ed. Washington DC US.

ISTA - INTERNATIONAL SEED TESTING ASSOCIATION. Determination of other seeds by number. In: International rules for seed testing. ed. 2008. Bassersdorf, c.4, pp.4.1-4.3 (2008).

Ji Y, Ao Z, Han J-A, Jane J-L and Bemiller JN (2004) Waxy maize starch subpopulations with different gelatinization temperatures. Carbohydrate Polymers, 57:177-190.

Lee JH and Cho KM (2012) Changes occurring in compositional components of black soybeans maintained at room temperature for different storage periods. Food Chemistry, 131:161-169.

Liu K, Mcwatters KH and Phillips RD (1992) Protein insolubilization and termal destabilization during storage as related to hard-tocook defect in cowpeas. Journal of Agricultural Food Chemistry, 40:2483-2487.

Luz MLS, Dalpasquale VA, Scapim CA, Braccini AL, Royer MR and Mora F (2005) Influência da umidade das sementes na capacidade de expansão de três genótipos de milho-pipoca (Zea mays L.). Acta Scientiarum Agronomy, 27:549553.

Malumba $P$, Janas $S$, Roiseux O, Sinnaeve G, Masimango $T$, Sindic $M$, Deroanne $C$ and Béra $F$ (2010) Comparative study of the effect of drying temperatures and heat-moisture treatment on the physicochemical and functional properties of corn starch. Carbohydrate Polymers, 79:633-641.

Miranda DS, Silva RR, Tanamati AAC, Cestari LA, Madrona GS and Scapim MR (2011) Quality assessment of popcorn. Revista Tecnológica, Edição Especial V Simpósio de Engenharia, Ciência e Tecnologia de Alimentos, 13-20.

Nasar-Abbas SM, Plummer JA, Siddique KHM, White PF, Harris D and Dods K (2008) Nitrogen retards and oxygen accelerates colour darkening in faba bean (Vicia faba L.) during storage. Postharvest Biology and Technology, 47:113-118. 
Paraginski RT, Vanier NL, Moomand K, Oliveira M, Zavareze ER, Silva RM, Ferreira CD and Elias MC (2014a) Characteristics of starch isolated from maize as a function of grain storage temperature. Carbohydrate Polymers, 102:88-94.

Paraginski RT, Vanier NL, Berrios JJ, Olivera M and Elias MC (2014b) Physicochemical and pasting properties of maize as affected by storage temperature. Journal of Stored Products Research, 59:209-214.

Park C-E, Kim Y-S, Park, K-J and K B-K (2012) Changes in physicochemical characteristics of rice during storage at different temperatures. Journal of Stored Products Research, 48:25-29.

Rani PR, Chelladurai V, Jayas DS, White NDG and Kavitha-abirami CV (2013) Storage studies on pinto beans under different moisture contents and temperature regimes. Journal of Stored Products Research, 52:78-85.

Reed C, Doyungan S, loerger B and Getchell A (2007) Response of storage molds to different initial moisture contents of maize (corn) stored at $25^{\circ} \mathrm{C}$, and effect on respiration rate and nutrient composition. Journal of Stored Products Research, 43:443-458.

Rehman Z-U, Habib F and Zafar SI (2002) Nutritional changes in maize (Zea mays) during storage at three temperatures. Food Chemistry, 77:197-201.

Rigueira RJA, Lacerda Filho $A F$ and Volk MBS (2009) Avaliação da qualidade do feijão armazenado em ambiente refrigerado. Alimentos e Nutrição, 20:649-655.

Sawazaki E, Morais JFL and Lago AA (1986) Influência do tamanho e umidade do grão na expansão da pipoca. South American Mushroom, 45:363-370.

Silva WSV, Vanier NL, Ziegler V, Oliveira M, Dias ARG and Elias MC (2014) Effects of using eolic exhausters as a complement to conventional aeration on the quality of rice stored in metal silos. Journal of Stored Products Research, 59:7681.

Singh N, Sandhu KS and Kaur M (2004) Characterization of starches separated from Indian chickpea (Cicer arietinum L.) cultivars. Journal of Food Engineering, 63:441-449.

Sirisoontaralak P and Noomhorm A (2007) Changes in physicochemical and sensoryproperties of irradiated rice during storage. Journal of Stored Products Research, 43:282-289.

Song A and Eckhoff SR (1994) Optimum popping moisture content for popcorn kernels of different sizes. Cereal Chemistry, St Paul, 71:458-460.

Vanier NL, Rupollo G, Paraginski RT, Oliveira M and Elias MC (2014) Effects of nitrogen-modified atmosphere storage on physical, chemical and technological properties of Carioca bean. Current Agricultural Science and Technology (CAST), 20:10-20.

Yousif AM, Batey IL, Larroque OR, Curtin B, Bekes $F$ and Deeth HC (2003) Effect of storage of adzuki bean (Vigna angularis) on starch and protein properties. LWT - Food Science and Technology, 36:601-607.

Zhou Z, Robards K, Helliwell S and Blanchard C (2003) Effect of rice storage on pasting properties of rice flour. Food Research International, 36:625634.

Zhou Z, Robards K, Helliwell S and Blanchard C (2010) Effect of storage temperature on rice thermal properties. Food Research International, 43:709-715.

Zinsly JR and Machado JA, Milho-pipoca. In: Melhoramento e produção de milho no Brasil. Piracicaba, ESALQ: Fundação Cargill, 1978, pp. 339-348. 